\title{
ANALISIS YURIDIS IMPLEMENTASI ASAS LEGALITAS DAN EQUALITY BEFORE THE $L A W$ DALAM UNDANG-UNDANG NARKOTIKA
}

\author{
Sunardi Riono ${ }^{1 *}$, Haris ${ }^{2}$ \\ ${ }^{1 *}, 2$ Magister Ilmu Hukum, DPPS UMM, Malang, Indonesia, titorachm4d@ gmail.com \\ (corresponding)
}

\begin{abstract}
This research will discuss about how the application of the principle of legality in Law No. 35 years old. 2009 regarding the regulation of the authority to arrest suspects in criminal acts of abuse and illicit trafficking of narcotics and narcotics precursors by Police Investigators, PPNS and BNN Investigators. This research is based on the type of normative juridical research. The results of the research show that Article 82 paragraph (2) should have originally only been up to the letter ' $h$ ', plus one point, namely the letter ' $i$ ' which has the formula: " $i$. The exercise of the authority to arrest referred to in letter $h$ is carried out in accordance with the provisions of Article 76 of this Law”.
\end{abstract}

Keywords: Legality; Equality Before the Law; Narcotics

\section{PENDAhUluan}

Dalam lingkup penegakan hukum pidana, kepekaan hati nurani para aparat penegak hukum dalam tugasnya secara Undang-undang merupakan suatu kebutuhan yang harus dilakukan untuk mewujudkan law inforcement dan keadilan yang substantif. Tanpa adanya kepekaan hati nurani, maka hukum yang terjadi hanya sebatas legalistic formalistis yang menghasilkan keadilan prosedural. Pernyataan tersebut bisa diibaratkan ketika dilakukan penyidikan secara represif terhadap seseorang yang diduga melakukan tindak pidana, maka penuntut umum atau seorang hakim saat menjatuhkan putusan harus mempertimbangkan antara kepentingan hukum dan kepentingan umum. Hal ini dikarenakan kedua kepentingan tersebut saling berhubungan satu dengan yang lain dan di harapkan bahwa seorang hakim, bukan hanya sekedar penegak hukum tetapi juga penegak keadilan (Ali, 2001).

Sudah selayaknya Penyidik, Penuntut umum dan Hakim tidak hanya melihat kejahatan yang terjadi dan mencocokkannya dengan unsur-unsur peraturan hukum pidana yang berlaku, akan tetapi harus mencoba menempatkan kejadian itu dengan mempertimbangkan pada proporsi yang sebenarnya. Terlebih bagi hakim sebagai garda terakhir dalam memeriksa dan menjatuhkan vonis kepada terdakwa dalam perkara tersebut. Sehingga putusan seorang hakim mampu menampung nilainilai hukum dan rasa keadilan yang hidup dan berkembang di masyarakat. Menurut Gustav Radbruch, 
idealnya vonis atau putusan hukum harus memenuhi atau mengandung tiga unsur yaitu nilai-nilai keadilan, kepastian hukum dan manfaat hukum (Mertokusumo, 2004).

Semenjak lahirnya Undang-Undang Nomor 8 Tahun 1981 tentang Kitab Undang-Undang Hukum Acara Pidana (Lembaran Negara Republik Indonesia Tahun 1981 Nomor 76, Tambahan Lembaran Negara Republik Indonesia Nomor 3 Tahun 2009). Terdapat beberapa hal baru yang bersifat fundamental apabila dibandingkan dengan Herziene Indiesche Reglement (HIR) yang juga dikenal dengan nama Reglement Indonesia yang diperbaharui (RIB). Beberapa hal baru yang tercantum dalam KUHAP tersebut antara lain masalah hak-hak tersangka dan terdakwa (Pasal $50 \mathrm{~s} / \mathrm{d}$ 68 KUHAP), bantuan hukum pada semua tingkat pemeriksaan (Pasal 69 s/d 74 HUHAP), penggabungan perkara perdata pada perkara pidana dalam hal ganti rugi (Pasal 89 s/d 101 KUHAP), pelaksanaan pengawasan putusan hakim (Pasal 277 s/d 283 KUHAP) dan wewenang hakim pada pemeriksaan pendahuluan, yakni praperadilan (Pasal 77 s/d 83 KUHAP).

Tujuan dari hukum acara pidana adalah untuk mencari dan mendapatkan atau setidak-tidaknya mendekati kebenaran materiil, yaitu kebenaran yang selengkap-lengkapnya dari suatu perkara pidana dengan menerapkan ketentuan-ketentuan hukum acara pidana secara jujur dan tepat. Untuk mencari pelaku dari suatu tindak pidana serta menjatuhkan pidana, menjaga agar yang tidak bersalah tidak dijatuhi pidana, meskipun orang tersebut telah dituduh melakukan tindak pidana. Syarat pertama untuk menindak suatu perbuatan pidana yaitu adanya suatu ketentuan dalam Undang-Undang pidana yang merumuskan perbuatan yang tercela itu dan memberikan sanksi terhadapnya. Di Indonesia, hal tersebut dikenal dengan asas legalitas yang terdapat di dalam Pasal 1 ayat (1) KUHP yang tertulis sebagai berikut: Suatu perbuatan tidak dapat dipidana, kecuali berdasarkan kekuatan ketentuan perundang-undangan pidana yang telah ada.

Suatu kegiatan, baik itu kegiatan masyarakat berbangsa maupun bernegara harus mempunyai cita-cita yang menjadi dasar agar tujuan kegiatan tersebut dapat tercapai dengan baik. Cita-cita yang menjadi dasar ataupun suatu kebenaran yang menjadi pokok dasar atau tumpuan berfikir atau berpendapat lazim disebut asas. Dengan demikian asas itu merupakan hal penting yang dapat dilihat dalam setiap tahapan pembangunan ditentukan adanya asas pembangunan nasional. Demikian pula di dalam hukum acara pidana juga ditentukan asas-asas yang menjadi prinsip pokok yang harus diterapkan dan dipegang teguh dalam melaksanakan atau menyelesaikan suatu perkara di lembaga peradilan.

Pasal 16 ayat (2) UU No. 8 Tahun 1981 tentang KUHAP tertulis: Bahwa untuk kepentingan penyidikan, seorang penyidik dan penyidik pembantu berwenang melakukan penangkapan. Tindak penangkapan itu sendiri perlu dibatasi artinya hanya dapat dilakukan terhadap seseorang yang diduga keras melakukan tindak pidana berdasarkan bukti permulaan yang cukup, sebagaimana yang diatur dan tertulis dalam Pasal 17 KUHAP menyatakan: Perintah penangkapan dilakukan terhadap seseorang yang diduga keras melakukan tindak pidana berdasarkan bukti permulaan yang cukup. Dalam KUHAP ada pembatasan tenggang waktu lamanya penangkapan terhadap seorang tersangka yang diduga melakukan tindak pidana dibatasi paling lama satu hari atau 1 x 24 jam.

Selain Penyidik kepolisian dan PPNS (Penyidik Pegawai Negeri Sipil) yang aturan mainnya diatur dalam KUHAP, dalam UU No. 35 Tahun 2009 tentang Narkotika terdapat pula Penyidik BNN (Badan Narkotika Nasional) yang juga diberi kewenangan melakukan penyidikan terhadap tindak 
pidana di bidang Narkotika dan Prekursor Narkotika. Dalam kewenangan tersebut salah satu diantaranya adalah kewenangan penangkapan terhadap tersangka sebagaimana diatur dan tertulis dalam Pasal 75 huruf g UU No. 35 Tahun 2009 tentang Narkotika. Akan tetapi terdapat perbedaan secara regulasi terkait dengan lamanya tenggang waktu penangkapan antara ketentuan Pasal 19 ayat (2) KUHAP yaitu selama 1 × 24 jam atau satu hari, sedangkan lamanya batas waktu penangkapan terhadap tersangka dalam ketentuan Pasal 76 ayat (1) dan ayat (2) UU No. 35 Tahun 2009 tentang Narkotika yaitu selama 3 × 24 jam atau tiga hari dan apabila waktu tersebut dirasa masih kurang, maka penangkapan dapat diperpanjang paling lama $3 \times 24$ jam atau tiga hari.

Dalam tindak pidana Narkotika terdapat pengaturan khusus (lex specialis) yaitu UndangUndang No. 35 Tahun 2009 tentang Narkotika khususnya kewenangan penyidik untuk melakukan penangkapan. Terkait adanya perbedaan ketentuan dalam KUHAP dengan UU Narkotika, jika kita membaca Pasal 81 UU Narkotika terdapat pengaturan secara jelas bahwa: Penyidik Kepolisian Negara Republik Indonesia dan Penyidik BNN berwenang melakukan penyidikan terhadap penyalahgunaan dan peredaran gelap narkotika dan prekursor narkotika berdasarkan Undang-Undang ini. Artinya bahwa selain Penyidik BNN, penyidik Polri juga berwenang menangani kasus Narkotika, sehingga dapat dipastikan akan terjadi diskriminasi perlakuan terhadap seorang tersangka penyalahgunaan dan peredaran gelap narkotika dan prekursor narkotika dalam hal lamanya batas waktu penangkapan.

Permasalahan yang dapat dipastikan terjadi dengan adanya dua regulasi mengatur hal yang sama yaitu konflik norma antara UU No. 8 Tahun 1981 tentang KUHAP dengan UU No. 35 Tahun 2009 tentang Narkotika, khususnya yang mengatur tentang penangkapan terhadap seseorang yang dicurigai sebagai pelaku tindak pidana penyalahgunaan Narkotika, dimana diskriminasi akan terjadi menyangkut perbedaan lamanya waktu penangkapan.

Permasalahan tersebut faktanya memang telah terjadi dalam praktek, dimana ditemukan oleh penulis bahwa Penyidik Polri Polresta Malang Kota dengan surat perintah penangkapan No. SP. Kap/239/IX/2019/Resnarkoba, melakukan penangkapan terhadap tersangka penyalahgunaan narkotika dengan batas waktu penangkapan selama 1 hari atau 1x24 jam, sedangkan penyidik BNN Kota Malang dengan surat perintah penangkapan No. Sp-Kap/ 2-BRTS / VIII / Ka / Pb.02 / 2019/BNNKo-MLG melakukan penangkapan terhadap tersangka penyalahgunaan narkotika dengan batas waktu penangkapan selama 3 hari atau $3 \times 24$ jam. Hal ini tentu sangat bertentangan dengan nilai-nilai keadilan dan perlindungan Hak Asasi Manusia atau melanggar asas universal yaitu equality before the law.

Masalah yang akan dikaji dalam penelitian ini adalah Bagaimana penerapan Asas Legalitas dalam Undang-undang No. 35 Tahun. 2009 terkait pengaturan wewenang penangkapan tersangka tindak pidana penyalahgunaan dan peredaran gelap narkotika dan prekursor narkotika oleh Penyidik Polri, PPNS dan Penyidik BNN; dan bagaimana konsep yang ideal tentang pengaturan kewenangan penyidikan dalam tindak pidana penyelahgunaan dan peredaran gelap narkotika dan prekursor narkotika. 


\section{METODE PENELITIAN}

Penulisan hukum ini didasarkan pada jenis penelitian yuridis normatif yaitu penelitian yang dilakukan dengan cara meneliti bahan pustaka atau data sekunder yang terdiri dari bahan hukum primer, bahan hukum sekunder dan bahan hukum tertier. Penelitian yuridis normatif ini akan membahas berdasarkan fakta dilapangan dan peraturan yang berlaku dalam kasus tindak pidana penyalahgunaan dan peredaran gelap narkotika dan prekursor narkotika yang menekankan pada segi hukum dengan mengadakan penelitian analisis langsung terhadap surat perintah penangkapan No. SP. Kap/239/IX/2019/Resnarkoba dan surat perintah penangkapan No. Sp-Kap/ 02BRTS/VIII/Ka/Pb.02/2019/BNNKo-MLG.

Selain itu metode yuridis normatif digunakan untuk mengkaji apa dasar pertimbangan penyidik Polri dan penyidik BNN menggunakan ketentuan Pasal 75 dan Pasal 81 UU No. 35/2009 tentang Narkotika dalam pertimbangan "surat perintah penangkapan" terhadap tersangka yang diduga melakukan tindak pidana penyalahgunaan dan peredaran gelap narkotika dan prekursor narkotika.

Jenis penelitian ini menggunakan (legal research), merupakan penelitian hukum berpijak pada hakikat ilmu hukum yang objeknya adalah norma. Sumber data penelitian ini menggunakan bahan hukum primer yang berdasar pada aturan hukum yang terdapat pada berbagai perangkat hukum atau peraturan perundang-undangan (UUD Negara Republik Indonesia Tahun 1945, KUHP, UU No. 8 Tahun 1981 tentang KUHAP, UU No. 35 Tahun 2009 tentang Narkotika, UU No. 39 Tahun. 1999 tentang HAM dan UU No. 10 Tahun. 2004 yang diganti dengan UU No. 12 Tahun. 2011 tentang pembentukan peraturan perundang-undangan. Selain itu penelitian ini juga menggunakan bahan hukum sekunder yang berdasar pada buku, majalah dan jurnal-jurnal ilmiah yang ada relevansinya terhadap penelitian tersebut.

Pendekatan yang digunakan dalam penelitian ini menggunakan 3 (tiga) macam pendekatan, yakni pendekatan Perundang-undangan (statute approach), pendekatan konseptual (conceptual approach) dan pendekatan kasus (case approach)(Marzuki, 2013).

\section{HASIL DAN PEMBAHASAN}

\section{Analisis Terhadap Asas Legalitas dan Implementasinya}

\section{Pentingnya Asas Legalitas Dalam Hukum Pidana}

Dalam hukum pidana terdapat asas yang dikenal dengan asas legalitas, di dalam KUHP yang berlaku di negara kita asas tersebut tercantum secara jelas dalam Pasal 1 ayat (1) yang tertulis "Suatu perbuatan tidak dapat dipidana, kecuali berdasarkan kekuatan ketentuan perundang-undangan pidana yang telah ada", dalam bahasa latin dikenal sebagai Nullum delictum nulla poena sine praevia lege poenali (tidak ada delik, tidak ada pidana tanpa peraturan lebih dahulu).

Asas tersebut sangat penting untuk diketahui bagi masyarakat khususnya bagi penegak hukum (Penyidik Polri, PPNS dan Penyidik BNN) yang mempunyai wewenang untuk melakukan penangkapan terhadap seseorang yang sudah ditetapkan sebagai tersangka. Dalam hal terjadinya tindak pidana penyalahgunaan dan peredaran gelap narkotika dan prekursor narkotika penyidik Polri, PPNS dan penyidik Badan Narkotika Nasional (BNN) sama-sama mempunyai kewenangan untuk melakukan penangkapan terhadap tersangka penyalahgunaan narkotika, sebagaimana ketentuan 
dalam Pasal 81 jo Pasal 75 huruf g dan Pasal 82 UU No. 35/2009 tentang Narkotika serta Pasal 16 UU No. 8 Tahun. 1981 tentang KUHAP.

Asas legalitas mengandung tiga pengertian (Moeljatno, 2000), yaitu:

a. Tidak ada perbuatan yang dilarang dan diancam dengan pidana kalau hal itu terlebih dahulu belum dinyatakan dalam suatu aturan Undang-undang;

b. Untuk menentukan adanya perbuatan pidana tidak boleh digunakan analogi (kiyas);

c. Aturan-aturan hukum pidana tidak berlaku surut.

Dalam UU No. 8 Tahun 1981 tentang KUHAP Pasal 1 butir 20 pengertian Penangkapan adalah suatu tindakan penyidik berupa pengekangan sementara waktu kebebasan tersangka atau terdakwa apabila terdapat cukup bukti guna kepentingan penyidikan atau penuntutan dan atau peradilan dalam hal serta menurut cara yang diatur dalam undang-undang ini (garis bawah oleh penulis). Membaca pengertian tersebut penangkapan tiada lain daripada "pengekangan sementara waktu" kebebasan tersangka atau terdakwa guna kepentingan penyidikan atau penuntutan. Akan tetapi, harus dilakukan menurut cara-cara yang telah ditentukan dalam KUHAP. Untuk itu, KUHAP telah menetapkan ketentuan tata cara tindakan penangkapan dalam Pasal 16 sampai dengan Pasal 19.

Pengekangan sementara waktu merupakan wujud pengurangan kebebasan dan hak asasi manusia itu harus dihubungkan dengan landasan prinsip hukum yang menjamin terpeliharanya harkat martabat kemanusiaan seseorang serta tetap berpedoman pada landasan orientasi keseimbangan antara perlindungan kepentingan tersangka pada satu pihak, dan kepentingan masyarakat serta penegakan ketertiban hukum pada pihak lain (Harahap, 2014).

Oleh karena penangkapan itu erat kaitannya dengan kebebasan hak asasi tersangka, Pasal 17 KUHAP tersirat alasan penangkapan atau syarat ketat dalam penangkapan yaitu seorang tersangka diduga keras melakukan tindakan pidana; dan dugaan yang kuat itu, didasarkan pada bukti permulaan yang cukup. Penyidik Polri, PPNS dan Penyidik BNN harus hati-hati betul dalam melakukan penangkapan terhadap tersangka tindak pidana narkotika, maka dari itu KUHAP betul-betul memberi batasan pada Penyidik Polri, PPNS dan Penyidik BNN.

Ada konsekuensi hukum jika syarat penangkapan itu dilanggar yaitu akan melahirkan upaya hukum praperadilan oleh tersangka, keluarga atau Penasehat Hukumnya sebagaimana Pasal 77 KUHAP dan melanggar Pasal 28-I ayat (1) UUD Negara Kesatuan Republik Indonesia Tahun 1945 menyatakan "Hak untuk hidup, hak untuk tidak disiksa, hak kemerdekaan pikiran dan hati nurani, hak beragama, hak untuk tidak diperbudak, hak untuk diakui sebagai pribadi di hadapan hukum, dan hak untuk tidak dituntut atas dasar hukum yang berlaku surut adalah hak asasi manusia yang tidak dapat dikurangi dalam keadaan apapun".

\section{Kewenangan Penangkapan oleh Penyidik Polri, PPNS dan Penyidik BNN dalam Perkara Narkotika}

Berbicara tentang arti atau makna kata "kewenangan", penulis telah melakukan analisis dengan berpedoman pada penjelasan yang ada di KBBI (Kamus Besar Bahasa Indonesia) dimana diperoleh data bahwa kata dasar dari "kewenangan" adalah "wenang" yang dimaknai "hak dan kekuasaan untuk melakukan sesuatu" Jika ditambah awalan kata "ber" menjadi "berwenang", maka memiliki arti atau 
makna "mempunyai" atau "mendapat" hak dan kekuasaan untuk melakukan sesuatu. Selanjutnya apabila kata "wenang" diberi awalan kata "ke" dan akhiran "an", maka menjadi kata "kewenangan", dimana dalam penjelasan di KBBI mempunyai arti "hal berwenang atau hak dan kekuasaan yang dipunyai untuk melakukan sesuatu (Badan Pengembangan dan Pembinaan Bahasa, 2019)”.

Dalam formulasi lain Ridwan HR menjelaskan lebih lanjut bahwa kewenangan (bevoegdheid) merupakan kekuasaan yang sah menurut hukum atau kekuasaan hukum suatu jabatan, dan mengandung arti kemampuan untuk melakukan tindakan-tindakan hukum tertentu, serta bersumber pada Undang-undang atau peraturan Perundang-undangan yang berlaku (HR, 2009).

Dalam perkara tindak pidana penyalahgunaan dan peredaran gelap narkotika dan prekursor narkotika, Penyidik Polri dan Penyidik BNN mempunyai kewenangan untuk melakukan penyidikan sebagaimana kewenangan yang telah diberikan oleh ketentuan Pasal 81 UU No. 35/2009 tentang Narkotika. Rumusan pasal 81 menyebutkan "Penyidik Kepolisian Negara Republik Indonesia dan penyidik BNN berwenang melakukan penyidikan terhadap penyalahgunaan dan peredaran gelap Narkotika dan Prekursor Narkotika berdasarkan Undang-Undang ini”.

Ketentuan tersebut secara jelas menjadi dasar bagi Penyidik Polri dan Penyidik BNN untuk melakukan langkah penyidikan jika terjadi tindak pidana penyalahgunaan dan peredaran gelap narkotika dan prekursor narkotika, agar perkara dimaksud menjadi terang tentang tindak pidana yang terjadi dan guna menemukan tersangkanya sebagaimana Pasal 1 angka 2 KUHAP. Sedangkan PPNS mempunyai kewenangan melakukan penyidikan tindak pidana penyalahgunaan narkotika berdasarkan pasal 82 UU No. 35/2009 tentang Narkotika.

Pasal 81 UU No. 35/2009 tentang Narkotika ini menjadi ruh bagi penegakan hukum yang dilakukan oleh Penyidik Polri dan Penyidik BNN dalam hal melakukan tindakan penangkapan terhadap seseorang yang telah diduga melakukan tindak pidana penyalahgunaan dan peredaran gelap narkotika dan prekursor narkotika, sebagaimana Pasal 75 huruf g menyatakan "Dalam rangka melakukan penyidikan, penyidik BNN berwenang: ... g. menangkap dan menahan orang yang diduga melakukan penyalahgunaan dan peredaran gelap Narkotika dan Prekursor Narkotika (bold dan garis bawah oleh penulis);

Secara tersurat Pasal 75 huruf g tidak menyebutkan Penyidik Polri mempunyai kewenangan untuk menangkap, akan tetapi Penyidik Polri mempunyai kewenangan penangkapan tersangka yang diatur dalam Pasal 16 ayat (2) KUHAP yaitu Untuk kepentingan penyidikan, penyidik dan penyidik pembantu berwenang melakukan penangkapan.

Dengan demikian timbul konflik atau kontroversi terhadap lamanya waktu penangkapan, mengingat penangkapan tersangka menurut Pasal 19 KUHAP dilaksanakan paling lama satu hari atau 1x24 jam, sedangkan penangkapan tersangka menurut pasal 76 UU No. 35 Tahun. 2009 dilaksanakan paling lama tiga hari atau 3x24 jam dan dapat diperpanjang paling lama tiga hari atau 3x24 jam. Secara substansi memerlukan penafsiran untuk mengatasi adanya perbedaan kewenangan lamanya waktu penangkapan terhadap seseorang yang di duga telah melakukan tindak pidana penyalahgunaan dan peredaran gelap narkotika dan prekursor narkotika yang dilakukan oleh Penyidik Polri, PPNS dan 
Penyidik BNN, karena sumber kewenangan penyidikan sama-sama diperoleh dari UU No. 35 Tahun. 2009 tentang Narkotika.

Berdasarkan hasil analisis tersebut diatas penulis menyimpulkan bahwa berdasarkan teori kewenangan, penyidikan terhadap tindak pidana penyalahgunaan dan peredaran gelap narkotika dan prekursor narkotika yang dilakukan oleh Penyidik Polri dan Penyidik BNN berasal dari Pasal 81, sedangkan untuk PPNS berasal dari pasal 82 UU No. 35/2009 tentang Narkotika, sehingga berbicara tentang kewenangan dan legalitas proses penyidikan yang dilakukan oleh Penyidik Polri, PPNS dan Penyidik BNN adalah sama-sama sah menurut aturan hukum yang berlaku.

Hal ini senada dengan pendapat dari Musthofa Sy dalam bukunya "Dualisme kewenangan pencatatan perceraian" yang menyatakan bahwa : Sesuai asas legalitas (legaliteitsbeginsel) kewenangan badan atau organ pemerintah berasal dari peraturan perundang-undangan. Secara teoritis, kewenangan yang bersumber dari peraturan perundang-undangan diperoleh melalui tiga cara yaitu atribusi, delegasi dan mandat" (Musthofa, 2015).

Sama-sama sah dalam hal kewenangan melakukan penyidikan terhadap tersangka tindak pidana penyalahgunaan dan peredaran gelap narkotika dan prekursor narkotika, tidak berarti Penyidik Polri dan PPNS tanpa kendala dalam melaksanakan kewenangan yang diberikan undang-undang kepadanya, khususnya menyangkut masalah dasar hukum pelaksanaan penangkapan dan lamanya waktu atau status tersangka dalam penangkapan. Fakta tersebut ditemukan peneliti, adanya inkonsistensi dari pembuat undang-undang dalam mengatur wewenang Penyidik Polri dan PPNS melakukan penyidikan tindak pidana penyalahgunaan dan peredaran gelap narkotika dan prekursor narkotika.

Sebagai contoh rumusan pasal 81 dengan jelas pembuat undang-undang memberi wewenang kepada Penyidik Polri untuk melakukan penyidikan perkara narkotika "berdasarkan undang-undang ini” maksudnya adalah Undang-undang No. 35 Tahun. 2009 tentang narkotika, namun ironisnya dalam rumusan pasal 75 secara tertulis pembuat undang-undang hanya memberi wewenang kepada "Penyidik BNN" untuk melakukan beberapa tindakan hukum terkait pelaksanaan penyidikan. Demikian juga PPNS diberikan wewenang melakukan penyidikan perkara penyalahgunaan Narkotika sesuai pasal 82 ayat (1), tetapi tidak ada kata-kata "berdasarkan undang-undang ini" sehingga konsekuensinya dalam melakukan penangkapan yang diatur pasal 82 ayat (2) huruf ' $h$ ' PPNS harus menggunakan dasar pasal 16 dan 19 KUHAP yang waktu penangkapannya paling lama satu hari atau $1 \times 24$ jam.

Yahya Harahap dalam bukunya "Pembahasan permasalahan dan penerapan KUHAP, penyidikan dan penuntutan" mengatakan, "Meskipun pada saat undang-undang dibuat rumusannya sudah diteliti berulang-ulang, sering terdapat undang-undang yang mengandung Error, bahkan bisa terjadi konflik atau kontroversi antara satu pasal dengan pasal lain dalam undang-undang yang bersangkutan yang disebut Conflict whitin the statutory" (Harahap, 2009).

Berdasarkan analisis peneliti tersebut diatas, maka peneliti menyimpulkan bahwa dalam pasal 75 pembuat undang-undang hanya memberi wewenang kepada Penyidik BNN dan bukan kepada Penyidik Polri. Jika pembuat undang-undang tidak menulis kata-kata "Penyidik Polri" dalam 
rumusan pasal 75 dengan alasan bahwa di dalam pasal 81 sudah ada kata-kata "berdasarkan undangundang ini”, yang artinya Penyidik Polri juga boleh melaksanakan semua kewenangan yang diberikan oleh pembuat undang-undang kepada Penyidik BNN sebagaimana dalam rumusan pasal 75, maka terjadi konflik atau kontroversi dengan rumusan pasal 87 ayat (1), pasal 90 ayat (1) dan pasal 92 ayat (1) undang-undang yang sama yaitu UU RI No. 35 Tahun. 2009 tentang narkotika, karena dalam tiga pasal tersebut pembuat undang-undang merumuskan dengan kata-kata yang lengkap yaitu "Penyidik Kepolisian Negara Republik Indonesia dan Penyidik BNN".

Fakta saat dikaji dan dianalisis peneliti, isi perintah atau wewenang yang diberikan pembuat undang-undang dalam pasal 87 ayat (1) hanyalah perintah melakukan penyegelan dan membuat Berita Acara Penyitaan, dimana wewenang itu sudah dimiliki oleh Penyidik Polri, sebagaimana diatur dalam pasal 45 ayat (3) dan (4) KUHAP, sedangkan isi pasal 90 ayat (1) tentang perintah melakukan penyisihan sebagian kecil barang sitaan, perintah itu juga sudah dimiliki oleh Penyidik Polri, sebagaimana diatur dalam pasal 45 ayat (3) KUHAP. Demikian pula pasal 92 ayat (1) tentang wajib memusnahkan tanaman narkotika, perintah senada dengan itu juga sudah diterima oleh Penyidik Polri, sebagaimana diatur dalam pasal 45 ayat (4) KUHAP.

Berdasarkan analisis pasal 81, penulis menyimpulkan bahwa kata-kata "berdasarkan undangundang ini" yang tertulis dalam pasal 81 mengandung pengertian yang sangat luas dan tidak jelas penggarisannya serta tidak ada kepastian. Yahya Harahap dalam bukunya "Pembahasan permasalahan dan penerapan KUHAP, penyidikan dan penuntutan" mengatakan : Ada ditemukan beberapa rumusan yang bersifat Broad Term. Sedemikian luasnya terminus atau rumusannya, menimbulkan permasalahan dalam praktek". Harahap, yahya (2009). Pembahasan permasalahan dan penerapan KUHAP, Jakarta: Sinar Grafika. Hal 14. Jadi faktanya apa yang dikemukakan Yahya Harahap betul-betul terjadi dalam UU No.35/2009 tentang narkotika ini (Harahap, 2009)".

\section{Keberlakuan Asas Lex Spesialis Derogat Lex Generalis}

Secara regulasi dan berdasarkan teori kewenangan tidak ada permasalahan bagi Penyidik Polri dan Penyidik BNN dalam melakukan kewenangannya untuk melakukan penyidikan terhadap pelaku tindak pidana penyalahgunaan dan peredaran gelap narkotika dan prekursor narkotika. Akan tetapi terhadap kegiatan "penangkapan tersangka" dalam praktik penegakan hukumnya terjadi perbedaan. Penyidik BNN menggunakan dasar hukum pasal 75 huruf g Undang-undang No. 35 Tahun. 2009 dengan lama waktu penangkapan tiga hari atau 3x24 jam, Penyidik Polri menggunakan dasar hukum pasal 75 dan 81 Undang-undang No. 35 Tahun. 2009 serta pasal 16 dan pasal 19 KUHAP, dengan lama waktu penangkapan satu hari atau 1x24 jam, akibatnya menimbulkan tindakan hukum yang berbeda antara Penyidik Polri dan Penyidik BNN, dalam menangkap tersangka perkara yang sama tetapi menerapkan batas waktu penangkapan yang berbeda.

Fakta hukum terkait dengan penerapan tindakan hukum yang berbeda atas lamanya batas waktu penangkapan tersebut, penulis dalam penelitiannya berhasil mendapatkan bukti surat perintah penangkapan baik dari pihak kepolisian maupun dari pihak BNN. Yang membuat semakin menarik dari hasil penelitian yang didapat oleh Penulis bahwa dasar hukum yang digunakan oleh penyidik Polri untuk melakukan penangkapan tertulis dalam "surat perintah penangkapan" menggunakan 
ketentuan Pasal 75 dan 81 UU No. 35/2009 tentang Narkotika (surat perintah penangkapan No. SP. Kap/239/IX/2019/Resnarkoba).

Begitu juga dengan Penyidik BNN dasar hukum yang digunakan untuk melakukan penangkapan tertulis dalam "surat perintah penangkapan" menggunakan ketentuan Pasal 75 UU No. 35 Tahun.2009 tentang Narkotika (surat perintah penangkapan No. Sp-Kap / 02-BRTS/VIII/Ka/Pb.02/2019/BNNKoMLG)

Berdasarkan fakta tersebut diatas jelas kedua penyidik memberlakukan batas waktu penangkapan yang berbeda. Penyidik Polri menggunakan batas waktu satu hari sebagaimana Pasal 19 ayat (1) KUHAP dengan bukti kalimat "surat perintah ini berlaku dari tanggal 8 September 2019 s/d 9 September 2019" (surat perintah penangkapan No. SP. Kap/239/IX/2019/Resnarkoba). Sedangkan Penyidik BNN dalam menerapkan lamanya batas waktu penangkapan tiga hari menggunakan Pasal 76 UU No. 35/2009 tentang Narkotika, sebagaimana bukti kalimat "surat perintah ini berlaku dari tanggal 31 Agustus 2019 s/d 02 September 2019” (surat perintah penangkapan No. Sp-Kap/ 02-BRTS/VIII/Ka/Pb.02/2019/BNNKo-MLG).

Perbedaan lamanya batas waktu penangkapan tersebut diatur dalam norma yang sejajar yaitu dalam UU No. 8 Tahun 1981 tentang KUHAP dan UU No. 35 Tahun 2009 tentang Narkotika. Dalam Pasal 76 lamanya waktu penangkapan menyatakan sebagai berikut:

a. Pelaksanaan kewenangan penangkapan sebagaimana dimaksud dalam Pasal 75 huruf $g$ dilakukan paling lama $3 \times 24$ (tiga kali dua puluh empat) jam terhitung sejak surat penangkapan diterima penyidik.

b. Penangkapan sebagaimana dimaksud pada ayat (1) dapat diperpanjang paling lama $3 \times 24$ (tiga kali dua puluh empat) jam.

Sedangkan jika dalam KUHAP Pasal 19 ayat (1) lamanya batas waktu penangkapan yang digunakan oleh Penyidik Polri ialah satu hari "Penangkapan sebagaimana dimaksud dalam Pasal 17, dapat dilakukan untuk paling lama satu hari”. Penyidik Polri tidak menggunakan Pasal 76 sebagai dasar batas waktu penangkapan melainkan menggunakan Pasal 19 ayat (1) KUHAP, karena Penyidik Polri berpendapat secara tersurat dalam Pasal 75 huruf g jelas tidak menyebutkan kewenangan penangkapan dimiliki oleh Penyidik Polri.

Sehingga Penyidik Polri berpendapat Pasal 76 yang mengatur tentang batas waktu lamanya penangkapan otomatis tidak berlaku terhadap penyidik polri. Fakta tersebut menunjukkan adanya konflik norma antara Pasal 16, Pasal 17, Pasal 19 ayat (1) UU No. 8 Tahun 1981 tentang Kitab Undang-undang Hukum Acara Pidana (KUHAP) dengan Pasal 75 huruf g, Pasal 76 dan Pasal 81 termasuk juga Pasal 82 Undang-undang No. 35 Tahun 2009 tentang Narkotika.

Jika terjadi konflik norma hukum (antinomi hukum) yang demikian, maka berlaku asas penyelesain konflik norma yang disebut asas preferensi hukum yaitu: Lex specialis derogat lex generalis, yaitu Undang-undang yang bersifat khusus menegasikan atau mengalahkan Undangundang yang bersifat umum. Jika terjadi konflik antara dua Undang-undang mengatur materi yang sama tetapi bertentangan satu sama lain, maka untuk mengatasi konflik tersebut berlaku prinsip 
Undang-undang yang bersifat khusus menegasikan atau mengalahkan Undang-undang yang bersifat umum (Mertokusumo, 2004).

Dengan demikian berdasarkan teori preferensi hukum diatas, penyidik Polri wajib menggunakan Pasal 81 UU No. 35 Tahun 2009 tentang Narkotika (lex spesialis) sebagai dasar penyidikan, namun batas waktu lamanya penangkapan terhadap pelaku tindak pidana penyalahgunaan dan peredaran gelap narkotika dan prekursor narkotika, tetap menggunakan Pasal 19 ayat (1) KUHAP (lex generalis).

Berawal dari keraguan Penyidik Polri yang berpendapat secara tersurat dalam Pasal 75 huruf g tidak menyebutkan kewenangan penangkapan tersebut dimiliki oleh Penyidik Polri, sehingga Penyidik Polri juga berpendapat Pasal 76 yang mengatur tentang batas waktu lamanya penangkapan otomatis tidak berlaku terhadap penyidik polri, maka penulis mempertajam penelitian atau analisis terhadap arti atau makna rumusan yang tertulis dalam pasal 75 UU No. 35 Tahun 2009 tentang Narkotika.

Kajian atau analisis dilakukan penulis dengan menggunakan metode "Interprestasi atau penafsiran hukum" dengan maksud dan tujuan untuk mendapatkan penjelasan yang gamblang mengenai arti atau makna teks pasal 75 UU No. 35 Tahun 2009 tentang Narkotika. Oleh karena penulis ingin mengetahui arti perkataan-perkataan dalam hubungannya satu sama lain dalam kalimatkalimat yang tertulis dalam pasal 75, maka penulis menggunakan interprestasi atau penafsiran "gramatikal atau tata bahasa". Andi Hamzah mengatakan: "Interprestasi atau penafsiran gramatika, artinya interprestasi ini didasarkan kepada kata-kata undang-undang. Jika kata-kata undang-undang sudah jelas, maka harus diterapkan sesuai dengan kata-kata itu walaupun seandainya maksud pembuat undang-undang lain” (Hamzah, 2010).

Terkait dengan penafsiran hukum tersebut diatas, menurut analisis peneliti jelas bahwa dalam rumusan pasal 75 pembuat undang-undang memberi wewenang khusus kepada Penyidik BNN bukan kepada Penyidik Polri. Wewenang dalam pasal 75 juga tidak diberikan kepada Penyidik Pegawai Negeri Sipil (PPNS) karena wewenang PPNS diatur tersendiri, sebagaimana dimaksud dalam pasal 82 UU No. 35 Tahun 2009 tentang Narkotika.

Selanjutnya penulis juga menganalisis pasal 75 menggunakan metode "interprestasi atau penafsiran sahih atau autentik atau resmi". C.S.T Kansil mengatakan : "bahwa interprestasi atau penafsiran sahih atau autentik atau resmi ialah penafsiran yang pasti terhadap kata-kata itu sebagaimana yang diberikan oleh pembentuk undang-undang, misalnya pasal 98 KUHP : "malam" berarti waktu antara matahari terbenam dan matahari terbit"(Kansil, 1989).

Berdasarkan penjelasan Kansil tersebut, jika dikaitkan dengan rumusan pasal 75 UU No. 35 Tahun 2009 tentang Narkotika, pembuat undang-undang merumuskan atau menulis dengan jelas katakata "Penyidik BNN berwenang" bahkan oleh pembuat undang-undang telah didefinisikan tentang siapa Penyidik BNN itu, sebagaimana yang tertulis dalam pasal 72 ayat (2) bahwa "Penyidik BNN sebagaimana dimaksud pada ayat (1) diangkat dan diberhentikan oleh Kepala BNN".

Dari hasil kajian atau analisis tersebut, menambah kejelasan kesimpulan penulis bahwa Penyidik BNN tidak sama dengan Penyidik Polri, karena sesuai ketentuan pasal 6 ayat 1 huruf a 
KUHAP Penyidik Polri adalah pejabat Polisi Negara Republik Indonesia yang syarat kepangkatannya diatur pasal 2 ayat 1 huruf a dan ayat 2, 3 dan 4 Peraturan Pemerintah No. 27 Tahun. 1983 tentang Peraturan Pelaksanaan Kuhap yang telah dirubah dengan pasal 2 huruf a, pasal 2A ayat 1, 2 dan 3, pasal 2B dan 2C Peraturan Pemerintah No. 58 Tahun. 2010 tentang perubahan atas Peraturan Pemerintah No. 27 Tahun. 1983 tentang Peraturan Pelaksanaan KUHAP.

\section{Analisis Konsep Ideal Tentang Pengaturan Kewenangan Penyidikan Tindak Pidana Narkotika oleh Penyidik Polri, Penyidik BNN dan PPNS}

\section{Tidak Ada Kepastian Hukum Dalam Penangkapan Tersangka Tindak Pidana Narkotika}

Berdasarkan analisis baik pada permasalahan 1 maupun 2 menurut penulis ada alasan yang mendasar bahwa antara rumusan pasal 75 dengan pasal 81 Undang-undang No. 35 Tahun. 2009 tentang narkotika tidak terjadi harmonisasi, dimana pasal 81 memberikan kewenangan penyidikan kepada Penyidik Polri, tetapi dalam rumusan pasal 75 yang diberi wewenang untuk melakukan berbagai macam tindakan hukum terkait penyidikan hanya Penyidik BNN.

Dampak dari konflik atau kontroversi itupun telah terjadi secara nyata antara Penyidik BNN dengan Penyidik Polri, dimana penerapan hukum dalam memberlakukan batas waktu penangkapan terhadap tersangka tindak pidana penyalahgunaan dan peredaran gelap narkotika dan prekursor narkotika mendapatkan perlakuan yang berbeda, Penyidik Polri menggunakan batas waktu satu hari atau 1x24 jam sebagaimana Pasal 19 ayat (1) KUHAP dengan bukti kalimat "surat perintah ini berlaku dari tanggal 8 September 2019 s/d 9 September 2019" (surat perintah penangkapan No. SP. Kap/239/IX/2019/Resnarkoba).

Sedangkan Penyidik BNN menerapkan lamanya batas waktu penangkapan paling lama tiga hari atau 3x24 jam, menggunakan dasar hukum Pasal 76 UU No. 35/2009 tentang Narkotika sebagaimana bukti kalimat "surat perintah ini berlaku dari tanggal 31 Agustus 2019 s/d 02 September 2019" (surat perintah penangkapan No. Sp-Kap/ 02-BRTS / VIII / Ka / Pb.02 / 2019 / BNNKo-MLG). Sehingga jaminan konstitusi Pasal 27 ayat (1) maupun Pasal 28-D dari UUD Negara Republik Indonesia Tahun 1945 maupun Pasal 3 ayat (2) Undang-undang No.39 Tahun. 1999 tentang HAM tidak didapatkan bagi tersangka tindak pidana penyalahgunaan dan peredaran gelap narkotika dan prekursor narkotika.

Data dan fakta yang diperoleh oleh peneliti pada saat study lapangan di Kantor Satuan Reserse Narkoba Polresta Malang Kota dan Kantor BNN Kota Malang tersebut diatas, apabila dianalisis berdasarkan teori keadilan yang disampaikan oleh Salim HS dalam Desertasinya, dimana ada tiga pengertian adil, yaitu: 1) tidak berat sebelah atau tidak memihak; 2) berpihak yang benar, dan 3) sepatutnya atau tidak sewenang-wenang. Jelaslah bahwa rasa keadilan tidak terwujud dalam diri tersangka dalam proses penyidikan tindak pidana narkotika (HS, 2012).

Selanjutnya apabila permasalahan tersebut diatas dilakukan analisis berdasarkan hasil tinjauan pustaka, dimana penulis mendapatkan beberapa literatur dan beberapa pendapat ahli yang mengemuka tentang ciri-ciri negara hukum salah satunya adalah A.V. Dicey yang menyebutkan bahwa tiga ciri penting "the rule of law" yaitu : 1) Supremacy of law 2) Equality before the law dan 3) Due process of law. Maka jelas sekali bahwa data dan fakta yang diperoleh peneliti dalam melakukan study 
lapangan berdampak merugikan dan mencederai konsep negara hukum, sebagaimana tertuang dalam pasal 1 ayat (3) UUD Negara Kesatuan Republik Indonesia Tahun. 1945.

Dengan demikian untuk mengatasi konflik dan menyerasikan antara rumusan pasal 75 dan pasal 81, maka perlu dilakukan revisi terhadap rumusan pasal 75 yang awalnya kalimat tertulis : "Dalam rangka melakukan penyidikan, penyidik BNN berwenang:"...... Penulis mengusulkan ada penambahan kalimat menjadi "Dalam rangka melakukan penyidikan, penyidik polri dan penyidik BNN berwenang".

Dengan adanya revisi rumusan pasal 75 tersebut, maka tidak ada keraguan bagi Penyidik Polri untuk melakukan penangkapan tersangka tindak pidana narkotika dengan lama waktu sebagaimana diatur dalam pasal 76, bahkan termasuk beberapa tindakan hukum yang sesungguhnya wewenang itu tidak dimiliki Penyidik Polri bisa dihindari, sebagai contoh : melakukan teknik penyidikan pembelian terselubung (Under cover buy) dan penyerahan di bawah pengawasan (Controlled delevery), sebagaimana diatur dalam pasal 75 huruf j Undang-undang No. 35 Tahun. 2009 tentang narkotika. Tindakan seperti itu sering dilakukan oleh Penyidik Polri, padahal pasal 75 hanya memberi wewenang kepada Penyidik BNN.

\section{Terjadi Inkonsistensi pengaturan wewenang penangkapan tersangka oleh Penyidik Polri, PPNS dan Penyidik BNN}

Dalam pembahasan permasalahan no. 1 dan 2 selain ditemukan rumusan pasal yang tidak menunjukkan harmonisasi di dalam Undang-undang No. 35 Tahun. 2009 tentang narkotika, peneliti dalam analisisnya juga menemukan rumusan pasal yang bersifat Conflict whitin the statutory yaitu konflik atau kontroversi antara rumusan pasal yang satu dengan yang lain, sebagaimana dalam pasal 81 pembuat undang-undang memberi kewenangan kepada Penyidik Polri dan Penyidik BNN, tetapi dalam rumusan pasal 75 tertulis dengan jelas pembuat undang-undang hanya memberi wewenang kepada Penyidik BNN.

Selanjutnya rumusan pasal 76 pembuat undang-undang memberikan kewenangan kepada Penyidik BNN bahwa waktu penangkapan tersangka paling lama tiga hari atau 3x24 jam dan dapat diperpanjang paling lama tiga hari atau 3x24 jam, ironisnya peneliti mendapat fakta tertulis dalam rumusan pasal 82 ayat (2) huruf ' $h$ ' pembuat undang-undang memberi wewenang penangkapan tersangka kepada Penyidik pegawai negeri sipil (PPNS), tetapi tidak ada kata-kata "berdasarkan undang-undang ini" sehingga berdasarkan Asas Lex specialis derogat lex generalis, PPNS harus menggunakan dasar penangkapan tersangka narkotika sebagaimana pasal 16 dan 19 ayat (1) KUHAP, dimana penangkapan terhadap tersangka hanya dilakukan dalam waktu satu hari atau 1x24 jam. Fakta tersebut diatas sudah barang tentu bertentangan dengan konsep negara hukum yang mengedepankan prinsip "Equality before the law" maupun asas keadilan dan kepastian hukum, sehingga harus bahkan wajib dicarikan solusi dan penyelesaiannya.

Berdasarkan landasan teori keadilan yang dikemukakan oleh Plato, dimana "konsep keadilan adalah erat kaitannya dengan kemanfataan. Sesuatu tersebut bermanfaat apabila sesuai dengan kebaikan. Sedangkan kebaikan merupakan substansi keadilan”. Penulis menyimpulkan bahwa fakta yang diperoleh dalam analisisnya yang menemukan rumusan pasal bersifat Conflict whitin the 
statutory yaitu konflik atau kontroversi antara rumusan pasal yang satu dengan yang lain di dalam Undang-undang No. 35 Tahun. 2009 tentang narkotika, merupakan hal yang sangat jauh dari nilai keadilan.

Dari hasil kajian atau analisis tersebut maka penulis membuat suatu konsep ideal yang sekiranya bisa mengatasi agar dalam Undang-undang No. 35 Tahun. 2009 tentang narkotika tidak terjadi inkonsistensi pengaturan wewenang penangkapan yang bersifat Conflict whitin the statutory, dengan cara merevisi rumusan pasal 82 sebagai berikut : Pasal 82 ayat (2) yang semula hanya sampai pada huruf ' $h$ '. Penulis mengusulkan ditambah satu point yaitu huruf 'i' yang rumusannya tertulis : “ $i$. Pelaksanaan kewenangan penangkapan tersebut pada huruf $h$ dilakukan sebagaimana ketentuan pasal 76 Undang-undang ini'.

\section{KESIMPULAN}

Setelah dilakukan analisis terhadap beberapa rumusan pasal yang ada dalam Undang-undang No. 35 Tahun. 2009 tentang narkotika, baik permasalahan 1, 2 dan 3, maka penulis atau peneliti menyimpulkan sebagai berikut:

1. Dalam pasal 81 Undang-undang No. 35 Tahun. 2009 tentang narkotika, terdapat rumusan pasal yang Broad Term atau kata-kata yang mempunyai pengertian sangat luas yaitu kata-kata "berdasarkan undang-undang ini" sehingga menimbulkan ketidakpastian bagi Penyidik Polri dalam melakukan penangkapan tersangka kasus narkotika, harus melakukan kewenangan seperti yang tertulis dalam rumusan pasal 75 dan 76 atau tidak, mengingat rumusan pasal 75 hanya tertulis "Penyidik BNN".

2. Dalam Undang-undang No. 35 Tahun. 2009 tentang narkotika, terdapat rumusan pasal yang bersifat Conflict whitin the statutory yaitu konflik atau kontroversi antara rumusan pasal yang satu dengan yang lain, sebagaimana dalam pasal 81 pembuat undang-undang memberi kewenangan kepada Penyidik Polri dan Penyidik BNN, tetapi dalam rumusan pasal 75 tertulis dengan jelas pembuat undang-undang hanya memberi wewenang kepada Penyidik BNN. Selanjutnya rumusan pasal 76 pembuat undang-undang memberi kewenangan kepada Penyidik BNN bahwa waktu penangkapan tersangka paling lama tiga hari atau 3x24 jam dan dapat diperpanjang paling lama tiga hari atau 3x24 jam, ironisnya pasal 82 ayat (2) huruf ' $h$ ' pembuat undang-undang memberi wewenang penangkapan tersangka kepada Penyidik pegawai negeri sipil (PPNS), tetapi tidak ada kata-kata "berdasarkan undang-undang ini" sehingga bisa dipastikan PPNS harus menggunakan dasar penangkapan tersangka narkotika sebagaimana pasal 16 dan pasal 19 ayat (1) KUHAP, dimana penangkapan terhadap tersangka hanya dilakukan dalam waktu paling lama satu hari atau $1 \times 24$ jam.

3. Berdasarkan kesimpulan diatas yang menunjukkan masih ada beberapa pasal Undang-undang No. 35 Tahun. 2009 tentang narkotika yang konflik atau kontroversi baik antara pasal yang satu dengan yang lain maupun antara pasal dalam Undang-undang No. 35 Tahun. 2009 tentang narkotika dengan pasal yang ada dalam undang-undang No. 10 Tahun. 2004 tentang pembentukan peraturan perundang-undangan yang telah diganti dengan Undang-undang No. 12 Tahun. 2011, 
maka untuk menyelesaikan konflik tersebut penulis membuat konsep ideal yang dapat dipergunakan oleh DPR-RI bersama Presiden, dengan cara merevisi terhadap pasal 75 dan 82 Undang-undang No. 35 Tahun. 2009 tentang narkotika, antara lain sebagai berikut:

a. Pasal 75 yang salah satunya mengatur mengenai kewenangan penangkapan. Penulis mengusulkan ada penambahan kalimat, yang awalnya kalimat tertulis: "Dalam rangka melakukan penyidikan, penyidik BNN berwenang:, Penulis mengusulkan ada penambahan kalimat menjadi "Dalam rangka melakukan penyidikan, penyidik polri dan penyidik BNN berwenang".

b. Pasal 82 ayat (2) yang semula hanya sampai pada huruf ' $h$ '. Penulis mengusulkan ditambah satu point yaitu huruf 'i' yang rumusannya tertulis: " $i$. Pelaksanaan kewenangan penangkapan tersebut pada huruf h dilakukan sebagaimana ketentuan pasal 76 Undangundang ini'.

\section{DAFTAR PUSTAKA}

Ali, A. (2001). Keterpurukan Hukum di Indonesia (Penyebab dan Solusinya). Ghalia Indonesia.

Badan Pengembangan dan Pembinaan Bahasa. (2019). Wenang. Badan Pengembangan Dan Pembinaan Bahasa. https://kbbi.web.id/wenang

Hamzah, A. (2010). Asas-Asas Hukum Pidana. PT. Rineka Cipta.

Harahap, M. Y. (2009). Pembahasan Permasalahan dan Penerapan KUHAP. Sinar Grafika.

Harahap, M. Y. (2014). Pembahasan Permasalahan dan Penerapan KUHAP, Penyidikan dan Penuntutan. Sinar Grafika.

HR, R. (2009). Tiga Dimensi Hukum Administrasi dan Peradilan Administrasi. FH UII Press.

HS, S. (2012). Penyelesaian Sengketa Tanah di Wilayah Kontrak Karya PT Newmont Nusa Tenggara. Universitas Brawijaya.

Kansil, C. (1989). Pengantar Ilmu Hukum dan Tata Hukum Indonesia. Balai Pustaka.

Marzuki, P. M. (2013). Penelitian Hukum. Prenada Media Group.

Mertokusumo, S. (2004). Mengenal Hukum Suatu Pengantar. Liberty.

Moeljatno. (2000). Asas-Asas Hukum Pidana (VI). PT Rineka Cipta.

Musthofa. (2015). Dualisme Kewenangan Pencatatan Perceraian. Intelegensia Media. 